\title{
INFO ARTHA

\section{ANALISIS PENERAPAN SISTEM PENGENDALIAN MANAJEMEN DENGAN MODEL FOUR LEVERS OF CONTROL DI PUSAT PENDIDIKAN DAN PELATIHAN BEA DAN CUKAI}

\author{
Satria Adhitama \\ Politeknik Keuangan Negara STAN \\ satria.bc@gmail.com \\ Dwi Rahma Ramadani Aulia \\ Politeknik Keuangan Negara STAN \\ dwirra@gmail.com
}

\section{INFORMASI ARTIKEL \\ Diterima Pertama \\ [08 Maret 2017] \\ Dinyatakan Diterima \\ [08 Juni 2017]}

KATA KUNCI:

levers; manajemen; organisasi; pengendalian; sistem.

\section{ABSTRAK}

Facing organizational growth and challenges, an organization needs a control system model to ensure that organization remains in control but does not restrict the freedom of employees to innovate and be creative. The research aimed at how the implementation of management control systems in Customs and Excise Training Center. The purpose of this study was to determine and describe the implementation of management control system using four levers of control model in the Customs and Excise Training Center. The concept used in this study is the concept of four levers of control. This study exploited constructivist paradigm with qualitative approach. Whereas, the data collection is carried out through literature study, semi-structured interview techniques and analysis of documents.

Dalam menghadapi kondisi organisasi yang semakin berkembang dan penuh tantangan, dibutuhkan suatu model sistem pengendalian yang dapat memastikan organisasi tetap terkontrol namun tidak membatasi kebebasan pegawai dalam berinovasi dan berkreasi. Penelitian ini melihat bagaimana penerapan sistem pengendalian manajemen di organisasi pemerintah. Tujuan dari penelitian ini adalah untuk mengetahui dan mendeskripsikan penerapan sistem pengendalian manajemen dengan model four levers of control di Pusdiklat Bea dan Cukai. Konsep yang digunakan dalam penelitian ini adalah konsep four levers of control. Penelitian ini menggunakan paradigma konstruktivis dengan pendekatan kualitatif. Sedangkan metode pengumpulan data dilakukan dengan studi kepustakaan, teknik wawancara semi terstruktur dan analisis dokumen. 


\section{PENDAHULUAN}

\subsection{Latar Belakang}

Menurut Mardiasmo (2009) bahwa setiap organisasi pasti memiliki tujuan. Tujuanlah yang membuat suatu organisasi tetap bergerak dinamis melakukan perubahan secara terus menerus guna mencapai tujuannya. Untuk memastikan tercapainya tujuan-tujuan tersebut, sebuah organisasi membutuhkan suatu sistem pengendalian.

Menurut Anthony dan Govindarajan $(2000,7)$ Sistem Pengendalian Manajemen (SPM) adalah sistem yang membantu para manajer untuk menjalankan organisasi kearah tujuan stratejiknya. Pengendalian manajemen yang efektif dipengaruhi oleh dua faktor; faktor formal dan informal. Faktor formal terdiri dari aturan-aturan dan sistem pengendalian manajemen, serta faktor informal yang terdiri dari etos kerja, budaya, gaya manajemen, organisasi informal, serta persepsi, dan komunikasi.

Goal Congruence atau keselarasan tujuan adalah tujuan utama dari suatu sistem pengendalian manajemen (Anthony dan Govindarajan 2000, 59). Dalam sebuah organisasi, masing-masing individu tentunya memiliki tujuan pribadi sendiri yang berbeda dari tujuan organisasinya. Peran sebuah sistem pengendalian lah yang menjembatani antara tujuan individu dan organisasi tersebut. Adanya keselarasan tujuan akan membuat semua bagian dalam organisasi bergerak bersama menuju arah yang sama. Dengan kata lain ketika tujuan organisasi tercapai, tujuan setiap individu dalam organisasi pun seharusnya terpenuhi bukannya terabaikan.

Pusdiklat Bea dan Cukai (Pusdiklat BC) dalam kurun waktu setidaknya lima tahun terakhir telah dapat mencapai target kinerja organisasinya dengan baik dan memimpin pencapaian target tersebut di antara eselon II di Badan Pendidikan dan Pelatihan Keuangan (BPPK). Namun dalam pelaksanaan tugas sehari-hari, berdasarkan hasil observasi, penulis menemukan sebuah fenomena dimana dalam pencapaian target tersebut terdapat banyak keluhankeluhan dari para pegawai yang menunjukkan masih adanya masalah goal congruence di Pusdiklat BC, dimana tujuan dari para individu masih terabaikan oleh organisasi. Hasil observasi penulis ini diperkuat oleh penelitian yang dilakukan oleh Adhitama (2011) dengan subjek penelitian Pusdiklat BC juga ditemukan bahwa walaupun budaya komunikasi di lingkungan Pusdiklat BC memiliki nilai kolektivis yang menekankan kerjasama, namun tidak semua anggota organisasi terlibat dalam mencapai tujuan tersebut. Selain itu masih adanya kesenjangan antara atasan dan bawahan membuat para bawahan kurang merasa dihargai dan belum dapat bekerja sepenuh hati.

Peneliti telah melakukan penelitian pendahuluan untuk menegaskan permasalahan yang ada di unit analisis dengan cara penyebaran kuesioner kepada
$30 \%$ jumlah populasi yaitu sebanyak 26 orang, dan terdapat 20 orang yang mengisi kuesioner lengkap pada pertanyaan tertutup serta 15 orang menjawab pertanyaan terbuka berupa identifikasi masalah. Berdasarkan hasil kuisioner yang dapat dilihat di lampiran 10, ditemukan masalah pengendalian manajemen formal dan informal yang masih ada di unit tersebut berdasarkan persepsi pegawai. Sebanyak 15 orang yang menjawab pertanyaan terbuka berupa identifikasi masalah, 3 orang diantaranya mengindentifikasi masalah pengendalian formal berupa aturan-aturan dan beban kerja, 11 orang mengidentifikasi masalah pengendalian informal berupa gaya kepemimpinan serta persepsi dan komunikasi dan 1 orang mengidentifikasi masalah teknis.

Seiring potensi perkembangan peran organisasi yang semakin kompleks berupa semakin besarnya peran Pusdiklat BC dalam memenuhi kebutuhan Direktorat Jenderal Bea dan Cukai sebagai user seiring dengan implementasi Masyarakat Ekonomi Asean (MEA) serta kebijakan Badan Pendidikan dan Pelatihan Keuangan (BPPK) yang akan mengarah kepada Corporate University, dan masih adanya tantangan dalam organisasi, sehingga diperlukan suatu model pengendalian yang dapat menjaga keseimbangan antara kebebasan berinovasi dan akuntabilitas, karena "both freedoms and accountability are desireable for effective public management" (Norman, 2001, 69). Untuk menciptakan manajemen publik yang efektif serta terwujudnya goal congruence demi tercapainya tujuan organisasi di masa depan dibutuhkan suatu sistem pengendalian manajemen yang dapat memastikan setiap anggota organisasi tetap terkontrol namun tidak mematikan kebebasan dalam berinovasi dan berkreasi. Menurut Robert Simos (1995, 7) terdapat dua sisi pengendalian ini telah dideskripsikan dengan model four levers of control. Model ini terdiri dari empat alat (tools) yang terdiri dari belief systems (misalnya nilai inti yang dimiliki organisasi), boundary system (misalnya kendali perilaku), diagnostic control systems (misalnya pemantauan kinerja) dan interactive control system (misalnya keterlibatan manajemen).

Berdasarkan pemaparan di atas, penulis menyusun penelitian dengan judul, "ANALISIS PENERAPAN SISTEM PENGENDALIAN MANAJEMEN DENGAN MODEL FOUR LEVERS OF CONTROL DI PUSAT PENDIDIKAN DAN PELATIHAN BEA DAN CUKAI."

Ruang lingkup penelitian ini adalah penerapan model Four Levers of Control yang diperkenalkan oleh Robert Simons. Model Four Levers of Control ini dijabarkan dalam empat tools, yaitu Belief Systems, Boundary Systems, Diagnostic Control Systems dan Interactive Control Systems.

Penelitian dilakukan pada perilaku pegawai yang berkaitan dengan pengendalian manajemen 
organisasi. Kegiatan pengendalian manajemen meliputi perencanaan yang harus dilakukan organisasi, koordinasi antar bagian, mengkomunikasikan informasi, mengevaluasi kinerja, memutuskan tindakan yang harus diambil dan mempengaruhi orang lain untuk mengubah perilaku mereka.

Penelitian dilakukan pada organisasi pemerintah yaitu Pusat Pendidikan dan Pelatihan Bea dan Cukai, Badan Pendidikan dan Pelatihan Keuangan.

Peneliatian ini bertujuan untuk Mendeskripsikan penerapan belief systems, boundary system, diagnostic control system, dan interactive control system di Pusdiklat BC. Selain itu penelitian ini memberi manfaat bagi Pusdiklat BC maupun peneliti selanjutnya yaitu:

1. Penelitian ini diharapkan dapat menjadi penyempurna dan perbaikan yang berkelanjutan mengenai penerapan kontrol strategi yang sudah berjalan selama ini di Pusdiklat Bea dan Cukai sehingga dapat terus mempertahankan kinerja terbaiknya dalam pencapaian visi-misi organisasi.

2. Penelitian ini diharapkan dapat memperkaya teori, berfungsi sebagai building block of science dan dapat membantu penelitian-penelitian selanjutnya mengenai penerapan model sistem pengendalian manajemen di organisasi pemerintah

3. Penelitian ini diharapkan menjadi wadah pengaplikasian ilmu pengetahuan yang diperoleh ke dunia nyata serta menggali pengetahuan yang lebih dalam mengenai sistem pengendalian manajemen.

\section{KERANGKA PEMIKIRAN}

\subsection{Konsep Sistem Pengendalian Manajemen}

Robert N. Anthony dan Vijay Govindarajan (2000, 1) menerangkan konsep pengendalian manajemen dengan diawali dengan pembagian elemen sistem pengendalian dalam empat elemen, yaitu:

1. Pelacak (detector) atau sensor: sebuah perangkat yang mengukur apa yang sesungguhnya terjadi dalam proses yang sedang dikendalikan.

2. Penaksir (assessor): suatu perangkat yang menentukan signifikansi dari peristiwa aktual dengan membandingkannya dengan beberapa standar atau ekspektasi dari apa yang seharusnya terjadi.

3. Effector: suatu perangkat (yang sering disebut "feedback") yang mengubah perilaku jika assessor mengindikasikan kebutuhan yang perlu dipenuhi.

4. Jaringan komunikasi: perangkat yang meneruskan informasi antara detector dan assessor dan antara assessor dan effector.

Keempat elemen tersebut dianalogikan dengan thermostat, dimana bagian-bagian thermostat yang berupa: (1) thermometer, sebagai detector yang mengukur suhu ruang; (2) assessor yang membandingkan suhu ruangan dengan suhu standar yang ditetapkan seharusnya terjadi; (3) effector, yang mendorong pemanas untuk memancarkan panas (jika suhu aktual lebih rendah dari suhu standar) atau mengaktifkan pendingin (jika suhu aktual lebih tinggi dari standar) dan juga yang memadamkan alat-alat ini ketika suhu ruangan telah sesuai dengan suhu standar; dan (4) jaringan komunikasi, yang meneruskan informasi dari thermometer ke assessor dan dari assessor ke elemen pemanas atau pendingin.

Pandangan yang menyamakan SPM dengan thermostat ini dipandang oleh Merchant dan Van der Stede $(2014,6)$ sebagai suatu pandangan kuno yang sempit. Mereka lebih memandang pengendalian manajemen secara luas yang melibatkan seluruh alat dan sistem yang digunakan manajer untuk memastikan bahwa perilaku dan keputusan terhadap karyawan konsisten dengan tujuan dan strategi perusahaan. Pengendalian manajemen melibatkan manajer pada beberapa tahapan untuk membantu memastikan bahwa karyawan melakukan apa yang terbaik bagi organisasi. Hal ini dipandang penting karena apa yang terjadi dalam organisasi ditentukan oleh orang yang ada dalam organisasi tersebut. Oleh karena itulah, pengendalian manajemen dipandang lebih berfokus pada pengendalian perilaku.

Merchant dan Van der Stede $(2014,10)$ memandang ada tiga kategori utama yang menjadi penyebab dalam masalah pengendalian manajemen, yaitu:

a. Kurangnya pengarahan.

b. Masalah motivasi.

c. Keterbatasan Individu.

Kegiatan pengendalian manajemen terdiri atas bermacam kegiatan, diantaranya (Anthony \& Govindarajan, 2000, 7):

a. Merencanakan apa yang seharusnya dilakukan organisasi.

b. Mengkoordinasikan kegiatan dari beberapa bagian organisasi.

c. Mengkomunikasikan informasi.

d. Mengevaluasi informasi.

e. Memutuskan tindakan apa yang seharusnya diambil jika perlu.

f. Mempengaruhi orang-orang untuk mengubah perilaku mereka.

Siklus pengendalian manajemen (management control cycle) menurut Anthony \& Govindarajan $(2000,17)$ meliputi aktivitas berikut:
a. Perencanaan stratejik.
b. Persiapan anggaran.
c. Pelaksanaan.
d. Evaluasi kinerja.

Sebuah sistem pengendalian yang memadai, setidaknya akan mampu memotivasi para individu yang terkait untuk tidak mempertentangkan upaya mereka dengan kepentingan perusahaan secara 
keseluruhan. Baik sistem formal maupun informal memiliki pengaruh pada individu dalam sebuah organisasi. Dalam menjalankan strategi organisasi secara efektif, kedua faktor tersebut harus dapat berjalan beriringan. Menurut Anthony \& Govindarajan $(2000,60)$, faktor informal dalam sistem pengendalian manajemen meliputi:

a. Faktor-faktor eksternal.

Faktor-faktor eksternal adalah norma-norma tentang perilaku yang diharapkan di dalam masyarakat, dimana organisasi perusahaan menjadi bagian di dalamnya. Norma ini mencakup etos kerja, yang diwujudkan melalui loyalitas pegawai terhadap organisasi perusahaan, keuletan mereka semangat mereka dan juga kebanggaan yang mereka miliki dalam menjalankan tugas (daripada sekadar menjalankan tugas tepat waktu).

b. Faktor-faktor internal.

Faktor-faktor internal dalam sistem pengendalian manajemen terdiri dari:

1) Budaya.

2) Gaya manajemen.

3) Organisasi informal.

4) Persepsi dan komunikasi.

Dalam upaya meraih tujuan organisasi, para manajer operasi harus tahu apa yang menjadi tujuan dan tindakan apa yang harus diambil untuk mencapainya.. Pesan-pesan yang diserap dari berbagai sumber pun bisa jadi bertentangan satu sama lain atau bahkan sangat beragam. Disinilah faktor persepsi dan komunikasi berpengaruh pada sistem pengendalian manajemen.

Faktor-faktor formal dalam sistem pengendalian manajemen menurut Anthony \& Govindarajan $(2000,64)$ yaitu:

a. Sistem pengendalian manajemen,

b. Aturan-aturan.

\subsection{Konsep The Four Levers Of Control}

Penelitian mengenai sistem pengendalian manajemen telah banyak dilakukan sebelumnya. Salah satu penelitian yang menjadi dasar bagi banyak penelitian tentang sistem pengendalian manajemen yang ada sampai saat ini adalah penelitian seorang professor Harvard University, Robert Simons tahun 1995. Simons $(1995,4)$ menjelaskan bahwa dalam filosofi lama kontrol dan manajemen menggunakan alur strategi dari atas ke bawah, bersifat standar, hasil yang dicapai didasarkan pada perencanaan, menempatkan sesuatu sesuai jalur serta tidak ada kejutan atau dinamika. Teknik pada filosofi lama ini tidak lagi sesuai untuk lingkungan yang kompetitif, yang mana kreatifitas, dan inisiatif karyawan menjadi perihal kritis dalam menentukan kesuksesan perusahaan. Filosofi yang baru lebih mengarahkan situasi pada customer driven strategy, kustomisasi, inovasi yang berkelanjutan, pemenuhan kebutuhan pelanggan dan pemberdayaan karyawan. Menurut Simons dalam jurnalnya yang berjudul "Control in an Age of Empowerment" (1995, 80), ketika organisasi semakin berkembang menjadi lebih kompleks, pengendalian dirasa menghambat kreativitas, ekperimen dan inisiatif karyawan. Hal inilah yang menjadi tantangan untuk mencari cara agar bisa mengembangkan pemberdayaan karyawan sekaligus mendorong akuntabilitas pekerjaannya (Simons, 1995, 80).

Simons $(1995,7)$ memperkenalkan sebuah model yang berfokus pada pencapaian strategi dalam sistem pengendalian manajemen. Model ini terdiri dari empat alat (tools) yang terdiri dari belief systems ( misalnya nilai - nilai inti yang jadi pedoman organisasi), boundary systems (misalnya kode etik perilaku), diagnostic control systems (misalnya pengukuran kinerja) dan interactive control system (misalnya keterlibatan manajemen). Keempat elemen tersebut dinamakan four levers of control. Kekuatan dari keempat elemen tersebut dalam mengimplementasikan strategi adalah ketika digunakan secara bersama-sama, bukan secara individual. Keempat elemen tersebut digambarkan pada gambar II.1:

\section{Gambar II.1. Four Levers of Control}

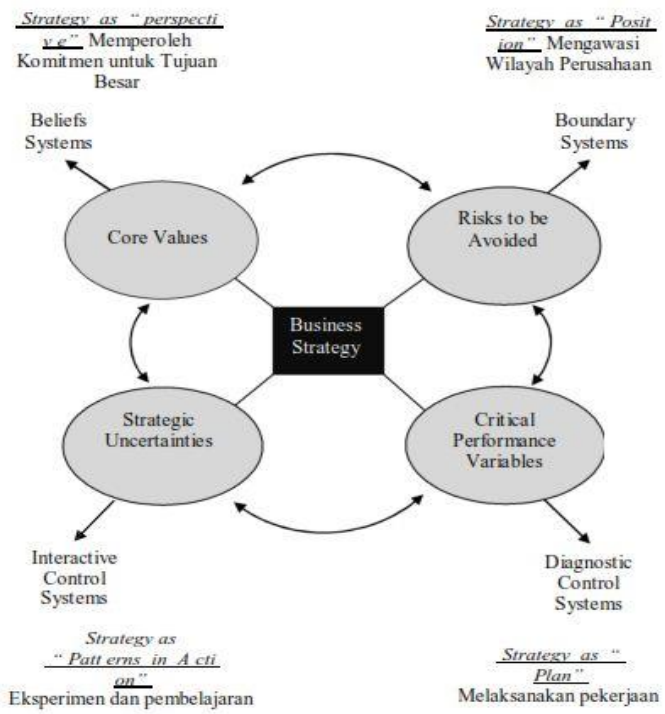

(diolah dari sumber : Simons, Robert. 1995. Levers of control: how managers use innovative control systems to drive strategic renewal. Boston: Harvard Business School Press. Hal.7)

\subsubsection{Belief Sysems}

Belief system atau sistem kepercayaan merupakan serangkaian definisi organisasi yang eksplisit yang dikomunikasikan oleh para manajer senior secara formal dan ditegakkan secara sistematis untuk memberikan nilai-nilai dasar, tujuan dan arahan bagi organisasi (Simons, 1995, 34). Sistem 
kepercayaan mengkomunikasikan nilai-nilai inti untuk memberikan inspirasi dan memotivasi karyawan untuk mencari, mengeksplorasi dan menciptakan serta melakukan usaha yang terkait tindakan yang tepat bagi organisasi.

Sistem kepercayaan ini diciptakan dan dikomunikasikan melalui dokumen-dokumen formal seperti pernyataan visi, misi atau tujuan (Simons, 1995, 34). Dengan pernyataan visi dan misi, manajer berusaha untuk menghadirkan perasan bangga dan arah yang dituju pada seluruh karyawan. Core values atau nilai-nilai dasar dan pernyataan visi-misi yang dikomunikasikan secara aktif akan menjadi pedoman untuk bertindak.

\subsubsection{Boundary systems.}

Sistem batas ini berlawanan dengan sistem beliefs. Sistem ini merupakan sistem formal yang membatasi domain atau wilayah yang bisa diterima dari aktivitas stratejik untuk para anggota organisasi (Simons, 1995, 39). Sistem batas digunakan oleh manajer puncak untuk membentuk batasan-batasan berupa aturan dan mengkomunikasikannya dengan tindakan yang harus dihindari oleh karyawan. Hal ini dilakukan agar karyawan bebas berinovasi dan berprestasi dalam bidang-bidang tertentu yang telah ditentukan sebelumnya. Bentuk dari boundary systems yaitu business conduct boundaries dan strategic boundaries (Simons, 1995, 42).

\subsubsection{Diagnostic control system.}

Sistem ini dimaksudkan untuk mendorong motivasi karyawan untuk bekerja dan menyelaraskan perilaku mereka dengan tujuan-tujuan organisasi. Sistem ini merupakan sistem umpan balik formal yang digunakan untuk memantau hasil organisasi dan mengoreksi penyimpangan yang terjadi dari standar kinerja yang ditetapkan sebelumnya (Simons, 1995, 59). Sistem ini juga melaporkan informasi faktor-faktor keberhasilan penting yang memungkinkan manajer untuk memfokuskan perhatiannya pada arahan organisasi.

Diagnostic control systems dapat dilakukan dengan beberapa metode (Simons, 1995, 61), yaitu:

- Profit/ business plan.

- Balance scorecard.

- Expense center budgets.

- $\quad$ Project monitoring systems.

- Brand revenue/ market share monitoring systems.

- Human resource plans.

\subsubsection{Interactive control system.}

Sistem pengendalian interaktif ini merupakan suatu sistem formal yang digunakan manajer puncak untuk secara teratur dan secara personal melibatkan mereka sendiri dalam aktivitas pengambilan keputusan dari bawahan (Simons, 1995, 95). Tujuan sistem ini adalah untuk fokus perhatian dan memaksakan dialog serta pembelajaran melalui organisasi dengan merefleksikan sinyal-sinyal yang dikirim oleh manajer puncak.

Fokus utama dari interactive control systems adalah strategic uncertainties. Strategic uncertainties adalah ancaman dan peluang yang muncul yang dapat membuat asumsi dari strategi bisnis yang saat ini tidak berlaku (Simons, 1995, 94). Interactive control system ini diharapkan dapat mengumpulkan dan menyimpulkan informasi-informasi yang berhubungan dengan efek dari strategic uncertainties pada strategi perusahaan/organisasi. Tujuan akhirnya adalah supaya organisasi/perusahaan tersebut dapat beradaptasi dengan ketidakpastian strategis sehingga pencapaian tujuan dari organisasi dapat berjalan lancar.

Berdasarkan kerangka pemikiran yang telah dipaparkan sebelumnya, penulis memutuskan untuk menggunakan konsep four levers of control untuk menganalisis penerapan sistem pengendalian manajemen di Pusat Pendidikan dan Pelatihan Bea dan Cukai.

\section{METODE PENELITIAN}

\subsection{Gambaran Umum Objek Penelitian}

Pusdiklat BC merupakan salah satu unit yang ada di Badan Pendidikan dan Pelatihan Keuangan (BPPK), yang memiliki tugas untuk membina diklat di bidang bea dan cukai sesuai dengan kebijakan yang ditetapkan oleh Menteri Keuangan dan berdasarkan peraturan perundang-undangan yang berlaku. Kantor Pusdiklat BC berlokasi di Jalan Bojana Tirta.

\subsubsection{Lingkungan pengendalian manajemen Pusdiklat BC. \\ Menurut Anthony dan Young $(2003,7)$} lingkungan pengendalian manajemen terdiri dari lingkungan eksternal dan internal. Begitu pula pengendalian manajemen yang ada di Pusdiklat BC.

\section{a. Lingkungan eksternal.}

Lingkungan eksternal menjadi penting karena dalam pengendalian manajemen harus mempertimbangkan aksi-aksi dari pelanggan atau klien, hambatan-hambatan dari penyedia dana dan badan legislatif serta norma dan adat setempat dimana organisasi berada (Anthony dan Young, 2003, 9). Pusdiklat BC terletak di Jalan Bojana Tirta III, Rawamangun, Jakarta Timur. Lokasi kantor Pusdiklat $\mathrm{BC}$ ini berjarak sekitar 300 (tiga ratus) meter dengan lokasi stakeholder utama yaitu kantor pusat Direktorat Jenderal Bea dan Cukai. Di dalam kantor Pusdiklat BC pun terdapat beberapa pesawat telpon yang memiliki sambungan dengan nomor ekstensi langsung ke kantor pusat DJBC. Hal ini menjadi sebuah keuntungan tersendiri dimana Pusdiklat BC dapat dengan cepat 
dan mudah dalam menjalin komunikasi dengan stakeholder utamanya.

Di sekitar kompleks Pusdiklat BC terdapat perkampungan rakyat yang sebagian besar masyarakatnya merupakan suku Betawi. Dalam keseharian selama jam kerja, gerbang masuk Pusdiklat $B C$ yang terdiri dari tiga gerbang, hanya dibuka salah satunya saja, yaitu gerbang utama. Namun ketika ada diklat kesamaptaan, gerbang utama tersebut ditutup dan kedua gerbang yang berada di bagian samping komplek kantor Pusdiklat BC dibuka. Setiap gerbang masuk diawasi oleh paling tidak dua orang Petugas Keamanan Dalam (PKD). Biasanya, setiap hari Jumat tiba, masjid di dalam komplek Pusdiklat BC terbuka untuk masyarakat sekitar yang ingin melakukan kegiatan ibadah sholat Jumat. Masjid tersebut juga terbuka untuk setiap waktu sholat. Terbukanya sebagian wilayah kantor terhadap masyarakat sekitar terkadang menjadi suatu risiko tersendiri, berupa keamanan barang-barang milik negara maupun pribadi anggota organisasi.

Lokasi Pusdiklat BC merupakan daerah rawan banjir dan seringkali terkena banjir ketika musim hujan datang. Kondisi semacam ini sangat merugikan Pusdiklat BC, khususnya apabila hal tersebut terjadi di tengah program diklat yang masih berjalan.

\section{b. Lingkungan internal.}

Lingkungan internal menjadi penting karena pengendalian manajemen mempengaruhi dan dipengaruhi oleh struktur organisasi, perilaku anggota organisasi, sistem informasi dan budaya organisasi (Anthony dan Young, 2003, 9). Pusdiklat BC memiliki struktur organisasi yang telah dijabarkan di awal bab. Sebagai organisasi pemerintah tentunya birokrasi adalah sebuah keharusan yang wajib diikuti setiap tahapannya. Paling tidak, di setiap dokumen tertulis tentang pelaksanaan tugas, tanda tangan atau paraf pejabat yang bertanggung jawab harus tertera sesuai pedoman tata naskah dinas Kementerian Keuangan.

Pusdiklat BC memiliki SDM yang sebagian besar berada pada usia produktif dan memiliki latar belakang pendidikan yang cukup tinggi, serta memiliki 13 widyaiswara yang kompetensinya sesuai dengan tugas dan fungsinya. Pusdiklat BC pun memiliki aset sendiri dengan fasilitas sarana dan prasarana yang lengkap. Hal ini menjadi kekuatan tersendiri bagi Pusdiklat BC dalam pelaksanaan tugas.

Kepala Pusdiklat BC selaku pimpinan tertinggi merupakan sosok yang tidak sungkan untuk berinteraksi dengan seluruh pegawai. Dengan kata lain, beliau melakukan management by walking. Setiap hari selama ada di tempat, Kapusdiklat BC ini selalu menyempatkan diri untuk berkeliling mengunjungi setiap bidang dan berkomunikasi secara terbuka dengan setiap pegawai. Tak jarang Kapusdiklat bercanda dengan para pegawainya dan mengetahui secara pasti siapa saja yang bertanggung jawab untuk tugas apa. Beliau juga cukup sering memberikan penugasan langsung ke pejabat atau pelaksana tanpa melalui jenjang birokrasi.

Namun disisi lain, suasana semi militer warisan dari DJBC tak dapat lepas begitu saja dari Pusdiklat BC. Interaksi dengan para siswa diklat yang cukup sering, dimana setiap siswa diklat diharuskan untuk melakukan penghormatan militer setiap berpapasan dengan para pegawai serta senioritas yang masih dijunjung tinggi, menjadi warna yang tidak dapat hilang pun dalam hubungan antara atasan dan bawahan di Pusdiklat BC. Walaupun pimpinan tertinggi sering membuka kesempatan berinteraksi, banyak bawahan yang masih merasa sungkan untuk menyampaikan aspirasinya secara langsung.

\subsection{Paradigma Penelitian}

Paradigma yang digunakan dalam penelitian ini adalah paradigma konstruktivis.karena lebih mewakili cara pandang penulis untuk menjelaskan kerangka sosial yang terbentuk dalam pola pikir individu maupun kelompok yang berdasar pada akal sehat tentang bagaimana subyek penelitian memberi makna pada suatu peristiwa dalam hidupnya (Poerwandari dalam Adhitama, 2011, 46).

\subsection{Pendekatan Penelitian}

Pendekatan penelitian yang penulis gunakan dalam penelitian ini adalah pendekatan kualitatif. Penelitian kualitatif menurut Creswell (2007, 4) merupakan metode-metode untuk mengeksplorasi dan memahami makna yang oleh sejumlah individu atau sekelompok orang dianggap berasal dari masalah sosial atau kemanusiaan. Alasan utama penulis menggunakan pendekatan kualitatif dalam penelitian ini karena dalam penelitian ini ingin melihat secara mendalam penerapan sistem pengendalian manajemen yang ada sehingga dapat memperoleh gambaran yang lengkap dari permasalahan yang dirumuskan dengan memfokuskan pada proses dan pencarian makna dibalik fenomena yang muncul dalam penelitian, dengan harapan agar informasi yang dikaji lebih bersifat komprehensif, mendalam, alamiah dan apa adanya. Selain itu penulis juga bermaksud untuk menganalisis kemungkinan penyempurnaan sistem dengan model four levers of control yang diperkenalkan oleh Robert Simons pada tahun 1995.

\subsection{Sifat Penelitian}

Sifat Penelitian ini yaitu bersifat deskriptif. Penelitian deskriptif adalah suatu penelitian yang berusaha menggambarkan atau menjelaskan secermat mungkin mengenai suatu fenomena dari data yang ada. Menurut Moleong $(2007,6)$ penelitian deskriptif kualitatif adalah penelitian yang bermaksud memahami fenomena tentang apa yang dialami oleh subjek penelitian, misalnya perilaku, persepsi, motivasi, tindakan, dll., secara holistik dengan cara 
deskripsi dalam bentuk kata-kata dan bahasa, pada suatu konteks khusus yang alamiah dan dengan memanfaatkan berbagai metode alamiah. Menurut Rakhmat dalam Adhitama (2011, 51) penelitian deskriptif adalah penelitian yang hanya memaparkan situasi atau peristiwa. Penelitian ini tidak mencari atau menjelaskan hubungan, tidak menguji hipotesis atau membuat prediksi (Moleong, 2007, 11).

Pemilihan metode ini berdasarkan pada pertimbangan bahwa dalam pembahasan penelitian ini akan memberikan gambaran mengenai penerapan sistem pengendalian manajemen dengan menggunakan model four levers of control di Pusdiklat bea dan cukai. Sifat penelitian deskriptif yang memberikan gambaran verbal dianggap sesuai dengan tujuan penelitian ini.

\subsection{Strategi Penelitian}

Strategi yang digunakan dalam penelitian ini adalah studi kasus. Penelitian studi kasus adalah suatu penelitian yang berusaha menemukan makna, menyelidiki proses dan memperoleh pengertian dan pemahaman yang mendalam dari individu, kelompok atau situasi (Emzir, 2014, 20). Tujuan dari studi kasus adalah untuk memperdalam pemahaman tentang realitas peristiwa pada konteks tertentu. Sederhananya, studi kasus mempertanyakan bagaimana dan mengapa pada suatu situasi tertentu, suatu peristiwa terjadi atau apa yang sedang terjadi (Adhitama, 2011, 49). Pemilihan strategi studi kasus didasarkan pada ketertarikan atau kepedulian penulis untuk memahami secara utuh penerapan sistem pengendalian manajemen di Pusdiklat BC dengan dilihat menggunakan model four levers of control.

\subsection{Metode Pengumpulan Data}

Dalam pengumpulan data sebagai bahan penulisan dan penyusunan penelitian ini, penulis akan menggunakan dua metode, yaitu study keputakaan dan penelitian lapangan berupa penelitian dokumen dan wawancara.

\subsection{Proses Analisis Data}

Setelah semua data terkumpul maka tahap selanjutnya adalah analisis data. Dengan melakukan analisis data, hasil penelitian lapangan sudah dapat dibaca dan berguna dalam menjelaskan masalah penelitian. Analisis data kualitatif menurut Bognan dan Biklen sebagaimana dikutip oleh Moleong (2007, 248), adalah upaya yang dilakukan dengan jalan bekerja dengan data, mengorganisasikan data, memilahmilahnya menjadi satuan yang dapat dikelola, mensintesiskannya, mencari dan menemukan pola, menemukan apa yang penting dan dipelajari, dan memutuskan apa yang dapat diceritakan kepada orang lain. Teknik analisis data kualitatif dilakukan secara bersamaan dengan proses pengumpulan data dan proses interpretasi data.
Analisis data yang digunakan dalam penelitian ini adalah hermeneutic empiris. Menurt Sumaryono $(1993)$ dalam Adhitama $(2011,54)$ proses hermeneutic dilakukan dengan cara membandingkan antara data yang diperoleh dengan kerangka pemikiran atau acuan konsep, kemudian digambarkan ulang dengan data empiris. Menurut Sumaryono dalam Bungin $(2014,193)$ pemahaman hermeneutic melibatkan tiga kelas ekspresi kehidupan, yaitu linguistik, tindakan dan pengalaman. Dalam penelitian ini hermeneutic empiris berarti bentuk interpretasi atas pengalaman yang dialami penulis selama penelitian berlangsung, dimana penulis membandingkan hasil wawancara dengan konsep four levers of control.

\subsection{Alasan Pemilihan Informan}

Dalam penelitian kualitatif, hal yang menjadi bahan pertimbangan utama dalam pengumpulan data adalah pemilihan informan. Berdasarkan teknik pemeriksaan keabsahan data, penulis menetapkan beberapa pegawai pada Pusdiklat BC sebagai informan dalam penelitian ini. Penetapan pegawai-pegawai tersebut sebagai informan dalam penelitian ini berdasarkan kriteria telah bekerja di Pusdiklat BC minimal 1 tahun, memahami serta pernah berkecimpung dalam aktivitas pengendalian yang berupa perencanaan strategis, pembentukan anggaran, pelaksanaan dan evaluasi kinerja serta bersedia dan memiliki waktu untuk diwawancarai.

\subsection{Triangulasi}

Triangulasi adalah teknik pemeriksaan keabsahan data yang memanfaatkan sesuatu yang lain. Di luar data itu untuk keperluan pengecekan atau sebagai pembanding terhadap data itu. Teknik triangulasi yang paling banyak digunakan ialah pemeriksaan melalui sumber lainnya. Denzin dalam Moleong (2012) membedakan empat macam triangulasi sebagai teknik pemeriksaan yang memanfaatkan penggunaan sumber, motede, penyidik, dan teori.

Dalam penelitian ini, triangulasi yang digunakan adalah triangulasi sumber yang berarti membandingkan dan mengecek balik derajat kepercayaan suatu informasi yang diperoleh melalui waktu dan alat yang berbeda dalam penelitian kualitatif. Hal itu dapat dicapai dengan jalan membandingkan data hasil pengamatan dengan data hasil wawancara, membandingkan apa yang dikatakan orang dikatakan orang di depan umum dengan apa yang dikatakannya secara pribadi, membandingkan apa yang dikatakan orang-orang tentang situasi penelitian dengan apa yang dikatakannya sepanjang waktu, membandingkan keadaan dan perspektif seseorang dengan berbagai pendapat dan pandangan orang biasa, dan membandingkan hasil wawancara dengan isi suatu dokumen yang berkaitan. 


\section{HASIL PENELITIAN}

\section{Analisis Belief Systems}

Dalam menganalisis belief systems, penulis akan berpusat pada analisis pernyataan visi-misi, value yang menjadi pedoman dalam pelaksanaan tugas dan metode penyampaian visi-misi serta value tersebut dari Top Management kepada seluruh pegawai di Pusdiklat BC.

Dari analisis belief systems yang telah dilakukan, maka dapat disimpulkan bahwa pernyataan visi-misi Pusdiklat BC telah memenuhi kriteria pernyataan visi dan misi yang baik menurut Bappenas, selaras dengan visi yang ingin dicapai BPPK sebagai eselon I, mendukung visi Kementerian Keuangan serta visi Presiden Republik Indonesia. Hal tersebut memperjelas peran Pusdiklat BC sebagai salah satu bagian penting pendukung tercapainya visi pembangunan yang ingin dicapai oleh Presiden Republik Indonesia.

Pernyataan nilai-nilai yang jadi pedoman di Pusdiklat BC juga mendukung nilai-nilai kementerian keuangan. Namun pada penerapannya, menurut hasil analisis data primer yang didapat penulis, dari kelima nilai-nilai kementerian keuangan hanya ada dua nilai yang dominan diterapkan di Pusdiklat BC yaitu nilai integritas dan pelayanan. Pusdiklat BC juga memiliki satu nilai pedoman unik yang tidak terdapat dalam pernyataan nilai-nilai kementerian keuangan namun tampak nyata dalam praktik operasional sehari-hari, yaitu nilai kedisiplinan.

Berdasarkan keragaman persepsi tanggapan dari informan terhadap pertanyaan tentang metode penyampaian visi-misi dimungkinkan telah terjadi adanya hambatan/rintangan dalam komunikasi organisasi sehingga komunikasi yang efektif tentang pernyataan visi-misi belum dapat tercapai. Namun di sisi lain, pengkomunikasian nilai-nilai organisasi melalui teladan langsung yang diberikan oleh pimpinan telah cukup efektif tersampaikan kepada para pegawai. Hal ini sejalan dengan pernyataan berikut:

"...the statements achieve their ends only if employees believe, by watching the actions of senior managers, that the company's stated beliefs represent deeply rooted values. If employees suspect that managers are going trough the motions of the lates fad, cynicism will set in." (Simons, 1995, 82)

Walaupun tidak semua pegawai hapal dengan pernyataan visi, misi, tujuan dan nilai-nilai organisasi, namun aksi nyata yang ditunjukan oleh manajer senior telah membuat para pegawai percaya bahwa mereka memiliki nilai yang mengakar yang menjadi pedoman dalam pelaksanaan tugas. Bagaimanapun juga, para pimpinan yang menggunakan pernyataan misi mereka sebagai dokumen berjalan (bukan sekadar dokumen yang jadi pajangan) dan menggunakannya sebagai bagian dari sistem yang dapat mengarahkan pola-pola perilaku pegawai sehingga selaras dengan tujuan perusahaan, maka dia telah menemukan suatu powerful lever of control (Simons, 1995, 82). Maka dapat ditarik kesimpulan bahwa Pusdiklat BC telah memiliki belief systems yang cukup baik sebagai sumber inspirasi para pegawainya.

\section{Analisis Boundary Systems}

Ketika berbicara tentang belief systems maka apa yang ingin dicapai oleh manajemen senior dengan menerapkan sistem tersebut adalah inspirasi bagi seluruh pegawai sehingga mendorong tumbuhnya inovasi dan kreativitas dalam mencapai apa yang dicita-citakan organisasi dengan berpegang pada nilainilai pedoman selama proses pencapaiannya. Sedangkan dalam boundary systems, perwujudan inovasi dan kreativitas tersebut harus dibuat batasanbatasannya sehingga jelas sejauh mana inovasi dan kreativitas itu diperbolehkan dalam organisasi.

Dalam menganilisis boundary systems, terdapat dua hal penting yang menjadi poin pembahasan, yaitu business conduct boundaries dan strategic boundaries. Business conduct boundaries merupakan kumpulan peraturan berupa pedoman perilaku yang dibuat dengan kalimat-kalimat negatif yang berisikan tindakan yang dilarang oleh perusahaan, sedangkan strategic boundaries merupakan batasan yang dinyatakan secara implisit tentang posisi pasar yang diinginkan perusahaan. Strategic boundaries menetapkan fokus suatu organisasi sehingga inovasi dan kreativitas apapun yang muncul dari anggotanya tidak keluar dari batasan yang ada.

Berdasarkan hasil wawancara dengan beberapa informan maka dapat disimpulkan bahwa Pusdiklat BC telah memiliki boundary system berupa business conduct boundaries dan strategic boundaries yang cukup dapat diandalkan. Namun, masih adanya kesalahan persepsi pada pegawai bahwa tidak adanya aturan-aturan tertulis yang ditetapkan, dan malah memandang peraturan yang sebenarnya peraturan tertulis tersebut sebagai aturan yang ditetapkan oleh top management secara lisan mengindikasikan masih adanya kekurangan dalam sosialisasi peraturanperaturan formal tersebut. Hal tersebut sesuai dengan pernyataan dari Kepala Pusdiklat BC bahwa "...Aturan yang membatasi adalah kode etik PNS, namun disini saya juga menegakkan aturan yang memang sebenarnya sudah ada namun memang belum tentu ditegakkan di tempat lain. Seperti misalnya memakai tidak boleh memakai sandal di kantor, ijin keluar selama jam kantor dsb. Sebenarnya itu sudah ada peraturan dari pemerintah seperti itu. Namun karena banyak yang tidak menegakkan, banyak yg beranggapan kalau aturan seperti itu hanya ada disini saja. Padahal ya saya tidak mengada-ada, 
aturan tersebut memang sudah ada, saya hanya menegakkannya di pusdiklat in" Selain itu beberapa pegawai khususnya pelaksana masih mempermasalahkan terkait dengan flexy time seharusnya diperbolehkan secara aturan namun oleh top management seolah-olah tidak diizinkan.

\section{Analisis Diagnostic Control Systems}

Sistem pengendalian diagnostik dalam Simons $(1995,59)$ dinyatakan sebagai sistem umpan balik formal yang digunakan untuk memantau manfaat yang dicapai organisasi serta mengoreksi penyimpangan yang tidak sesuai dengan standar kinerja organisasi. Sistem ini memiliki tujuan untuk memotivasi karyawan untuk menyelaraskan perilakunya dengan tujuan organisasi. Penerapan sistem ini diantaranya dilakukan dengan membuat planning system, budget dan pengukuran kinerja dengan menggunakan balance score card (Simons, 1995, 61).

Pusdiklat BC telah menerapkan diagnostic control system berupa planning system yang diwujudkan dalam dokumen renstra 2015-2019, menerapkan budgeting berupa anggaran berbasis kinerja dan memiliki pengukuran kinerja berbasis balance score card. Pada pelaksanaan anggaran secara umum masih memerlukan banyak penyesuaian ketika kegiatan sudah berjalan. Kurangnya koordinasi terkait pelaksanaan anggaran ini masih menjadi hambatan dalam perbaikan di organisasi.

Dalam penetapan target IKU individu, masih terdapat kekurangan yang merupakan bagian dari risiko diagnostic control system yaitu menetapkan target yang mudah dicapai dan kemungkinan pengukuran variabel yang salah. Kedua hal tersebut dapat menyebabkan timbulnya hambatan bagi organisasi untuk mencapai perbaikan terus-menerus ke arah yang lebih baik.

Hal tersebut sejalan dengan apa yang diungkapkan oleh beberapa informan termasuk Kepala PUsdiklat BC “...sejauh ini penerapan anggaran berbasis kinerja memang belum benar-benar ideal. Namun mulai 2016 ini rencananya money follow function itu akan benar-benar diterapkan. Selama ini memang banyak terjadi penyesuaian atau revisi terhadap POK. Saya melakukan hal tersebut sesuai kebutuhan dan prioritas pusdiklat bc, bukan hanya semata karena keinginan saya. Dana-dana tersebut pun hasil optimalisasi. Jadi daripada tidak terpakai, lebih baik saya gunakan ke hal yang memang membutuhkan..." dan "...IKU eselon II itu ada yang given, namun ada juga yang bisa dinegoisasikan sesuai kemampuan. Karena pada dasarnya kita sendiri yang mengetahui kemampuan kita seperti apa..."

\section{Analisis Interactive Control System}

Dalam menganalisis interactive control system tentu tidak dapat dilepaskan dari strategic uncertainties. Strategic uncertainties menurut Simons (1995, 94) merupakan hambatan-hambatan dan peluang yang dapat muncul dan dapat mengakibatkan asumsi-asumsi yang mendasari strategi bisnis yang sedang berjalan jadi tidak dapat lagi diterapkan perusahaan. Contoh dari strategic uncertainties antara lain: perkembangan teknologi, perubahan demografi populasi dan perubahan kebijakan pemerintah.

Dari pembahasan mengenai strategic uncertainties dapat diartikan bahwa Pusdiklat BC menghadapi perubahan strategis yang memiliki dampak pada implementasi rencana strategis organisasi. Dalam menghadapi perubahan yang ada, fokus Pusdiklat BC lebih mengarah ke pemenuhan perubahan kebutuhan user dan menyelaraskan perubahan itu terhadap produk utama organisasi, yaitu diklat.

Pusdiklat BC sudah menerapkan interactive control system yang dilaksanakan dengan baik oleh top management melalui upaya-upaya pembukaan forum diskusi dimana setiap pegawai bebas berdialog disana. Namun masih adanya kendala dalam penerapan interactive control system di lapisan lower management masih menjadi suatu hambatan yang harus ditindaklanjuti.

Hal tersebut berdasarkan hasil wawancara beberapa informan termasuk Kepala Pusdiklat BC "Dalam menghadapi hal-hal tersebut saya membuka kesempatan orang-orang luar untuk ikut mengajar di pusdiklat. Hal itu bukan dengan maksud menimbulkan kompetisi dengan para widyaiswara, justru saya pikir hal tersebut akan membuat semua pihak terus belajar dan meningkatkan kualitas dirinya. Selain itu Kepala Pusdiklat BC juga mengungkapkan "pertama, saya tidak ingin ada masalah atau hambatan komunikasi di bawah yang dapat mengakibatkan dampak ke pencapaian tujuan. Jadi terkadang memang saya lebih tahu tentang suatu masalah daripada kabid/kasubbid. $\mathrm{Hal}$ ini terjadi karena saya sering berkomunikasi dengan pelaksana. Saya sadar bahwa ketika saya tidak ada di tempat, pekerjaan tetap dapat terselesaikan, namun ketika para pelaksana yang tidak ada di tempat maka kerjaan tidak akan selesai. Kedua saya juga tidak ingin pegawai takut dengan saya. Karena rasa takut menyebabkan tidak mau berbicara ketika ada suatu hambatan. Beberapa hari yang lalu saya baru saja membuka forum untuk menampung keluhan pegawai. saya tidak ingin ketika IKU tercapai hijau semua tapi dalam mencapai itu ada ketidakbahagiaan, ibarat saya menginjak punggung orang-orang tersebut. Saya ingin semua happy, maka saya buka forum itu."

\section{Triangulasi}

Triangulasi ahli yang penulis lakukan dengan mewawancarai Bapak Muh. Nur Khamid. Seorang mantan pejabat eselon IV Pusdiklat BC yang pernah bekerja di Pusdiklat BC selama kurang lebih 7 tahun 
mulai dari tahun 2007 s.d. 2014. Beliau pernah menduduki posisi di semua bidang yang ada di Pusdiklat BC, baik Bidang Perencanaan dan Pengembangan Diklat, Bidang Penyelenggaraan maupun Bidang Evaluasi dan Pelaporan Kinerja. Beliau juga memiliki latar belakang pendidikan di akuntansi dan manajemen, serta sering terlibat dalam kegiatan pengendalian di Pusdiklat BC.

Penulis mengkonfirmasi tentang penerapan sistem pengendalian manajemen dengan model four levers of control di Pusdiklat BC. Belief system di Pusdiklat BC beliau nyatakan dengan adanya konsistensi tentang nilai kedisiplinan selama beliau bertugas di Pusdiklat BC. Boundary system dinyatakan beliau dengan adanya batasan terkait inovasi yang berhubungan dengan user, namun kreativitas pelaksana tidak dibatasi. Diagnostic control system di Pusdiklat BC digambarkan beliau sebagai target IKU dalam penyerapan anggaran, yang selalu dapat menggerakkan seluruh anggota organisasi untuk mencapai hal tersebut. Sedangkan tentang interactive control system, beliau nyatakan bahwa dalam menghadapi strategic uncertainties, Pusdiklat BC sejak dahulu selalu menjaga hubungan dengan user sehingga dapat selalu meng-capture kebutuhan user dengan cepat. Dari hasil wawancara pun beliau mengkonfirmasi bahwa konsep model four levers of control ini dapat diterapkan dalam menganalisis sistem pengendalian manajemen di Pusdiklat BC.

\section{PENUTUP}

\section{Simpulan}

Dari pembahasan di atas dapat disimpulkan

beberapa hal sebagai berikut:

1. Pusdiklat $\mathrm{BC}$ telah menerapkan belief system yang menjadi sumber inspirasi dalam setiap pelaksanaan tugas. Pernyataan nilai-nilai yang menjadi pedoman di Pusdiklat BC juga mendukung nilai-nilai Kementerian Keuangan. Namun dalam penerapannya, dari kelima nilai-nilai Kementerian Keuangan hanya ada dua nilai yang dominan diterapkan di Pusdiklat BC yaitu nilai integritas dan pelayanan. Pusdiklat BC juga memiliki satu nilai unik berupa kedisiplinan yang berasal dari sejarah Pusdiklat BC sebagai bagian DJBC di masa lalu. Berdasarkan keragaman persepsi tanggapan dari informan terhadap pertanyaan tentang metode penyampaian visi-misi dimungkinkan telah terjadi adanya hambatan/rintangan dalam komunikasi organisasi sehingga komunikasi yang efektif tentang pernyataan visi-misi belum dapat tercapai. Namun di sisi lain, pengkomunikasian nilai-nilai organisasi melalui teladan langsung yang diberikan oleh pimpinan telah cukup efektif tersampaikan kepada para pegawai.

2. Pusdiklat BC telah menerapkan boundary system berupa business conduct boundaries dan strategic boundaries yang cukup dapat diandalkan. Namun, masih adanya kesalahan persepsi pada pegawai bahwa tidak adanya aturan-aturan tertulis yang ditetapkan, dan malah memandang peraturan yang sebenarnya peraturan tertulis tersebut sebagai aturan yang ditetapkan oleh top management secara lisan mengindikasikan masih adanya kekurangan dalam sosialisasi peraturanperaturan formal tersebut.

3. Pusdiklat BC menerapkan diagnostic control system berupa planning system yang diwujudkan dalam dokumen renstra 2015-2019, menerapkan budgeting berupa anggaran berbasis kinerja dan memiliki pengukuran kinerja berbasis balance score card. Pada pelaksanaan anggaran secara umum masih memerlukan banyak penyesuaian ketika kegiatan sudah berjalan. Kurangnya koordinasi terkait pelaksanaan anggaran ini masih menjadi hambatan dalam perbaikan di organisasi. Dalam penetapan target IKU individu, masih terdapat kekurangan yang merupakan bagian dari risiko diagnostic control system yaitu menetapkan target yang mudah dicapai dan kemungkinan pengukuran variabel yang salah. Kedua hal tersebut dapat menyebabkan timbulnya hambatan bagi organisasi untuk mencapai perbaikan terusmenerus ke arah yang lebih baik.

4. Pusdiklat BC sudah menerapkan interactive control system yang dilaksanakan dengan baik oleh top management melalui upaya-upaya pembukaan forum diskusi dimana setiap pegawai bebas berdialog disana. Namun masih adanya kendala dalam penerapan interactive control system di lapisan lower management masih menjadi suatu hambatan yang harus ditindaklanjuti.

\section{Saran}

1. Sebagai solusi dari kurangnya pengetahuan pegawai tentang pernyataan visi-misi organisasi yang baru, penulis memberikan rekomendasi untuk melakukan internalisasi yang tidak hanya dalam pertemuan formal, tapi juga dalam bentuk peletakan banner bertuliskan pernyataan visi-misi Pusdiklat BC di bagian-bagian strategis di lingkungan kantor Pusdiklat BC. Saat ini ada beberapa plang bertuliskan kata-kata motivasi di lingkungan kantor, alangkah baiknya apabila pernyataan visi tersebut disajikan dalam bentuk serupa sehingga para pegawai maupun user mengetahui apa yang dicita-citakan Pusdiklat BC.

2. Mengatasi kesalahan persepsi tentang aturan formal yang dianggap sebagai aturan yang 'hanya' ditetapkan oleh Kapusdiklat, menurut penulis dalam setiap kesempatan dimana Kapusdiklat menyampaikan aturan-aturan tersebut, perlu ditambahkan bentuk aturan tersebut secara tertulis kepada para pegawai.

3. Terhadap penetapan target IKU yang memiliki risiko target mudah dicapai dan kesalahan variabel 
pengukuran, negosiasi terhadap penetapan target tersebut harus dijadikan kegiatan wajib sebelum penetapan target.

4. Solusi atas masih adanya lower management yang belum menerapkan interactive control adalah top management perlu mewajibkan untuk para pejabat agar melaksanakan interactive control seperti apa yang telah beliau lakukan. Kesamaan penerapan di semua level manajemen akan memberikan arahan yang pasti bagi para pegawai dalam menentukan langkah di kondisi yang sedang menghadapi banyak perubahan. Penyediaan sarana mengungkapkan keluhan yang disampaikan dengan tertutup (anonym) pun perlu disediakan. Hal ini dimaksudkan untuk mengakomodir keluhan-keluhan yang tak terungkapkan karena rasa segan dan kekhawatiran tertentu pada pimpinan.

\section{DAFTAR PUSTAKA (REFERENCES)}

Adhitama, Satria, Analisis Budaya Komunikasi pada Organisasi Pemerintah, Tesis, Universitas Indonesia, Depok, 2011.

Anandita, Dita, Analisis Kemungkinan Penerapan Sistem Pengendalian Manajemen dengan Model Four Levers of Control di Bank of China Cabang Jakarta, Tesis, Universitas Gadjah Mada, 2014.

Anthony, Robert N., dan Govindarajan, Vijay, Sistem Pengendalian Manajemen, Jakarta:Salemba Empat, 2000

Anthony, Robert N., dan Young, David W., Management Control in Nonprofit Organizations, New York : McGraw-Hill, 2003.

Bungin, Burhan, Penelitian Kualitatif, Jakarta:Prenada Media Group, 2007.

Chapman, Christopher S., Controlling Strategy: Management, Accounting and Performance Measurement, New York: Oxford University Press Inc.,2005.

Creswell, John W., Research Design: Qualitative and Quantitative Approaches. Amerika: SAGE Publications, 1994.

Emzir, Metodologi Penelitian Kualitatif: Analisis Data, Depok: Rajawali Press, 2014.

Handary, Ariana Restu, Analisis Penerapan Four Levers of Control: Studi Kasus pada PT Taspen
(Persero), Tesis, Universitas Indonesia, Depok, 2013.

Herdiansyah, Haris, Wawancara, Observasi, dan Focus Group Sebagai Instrumen Penggalian Data Kualitatif, Jakarta: PT Raja Grafindo Persada, 2015.

Hery, Soal-Jawab Sistem Pengendalian Manajemen, Jakarta: Bumi Aksara, 2011.

Langfield, Kim., Smith, Management Control Systems and Strategy: A Critical Review, Great Britain: Elsevier Science Ltd, 1997.

Lekatompessy, Jantje Eduard, Peran Sistem Pengendalian Manajemen dalam Meningkatkan Kinerja Perusahaan: Analisis Kontijensi dan Resource-Based View, Disertasi, Universitas Diponegoro, Semarang, 2012.

Mardiasmo, Akuntansi Sektor Publik. Yogyakarta, ANDI, 2009.

Moleong, Lexy J., Metodologi Penelitian Kualitatif, Bandung: PT Remaja Rosdakarya, 2007.

Mursaleh, H., Pedoman Membuat Skripsi Atau Tesis, Jakarta: CV Haji Masagung, 1989.

Mutiah, Andi, Analisis Sistem Pengendalian Manajemen dan Akuntabilitas Kinerja dalam Mewujudkan Good Governance (studi kasus Inspektorat Jenderal Departemen Agama R.I), Skripsi, UIN Syarif Hidayatullah, Jakarta, 2009Merchant, Kenneth A., Van der Stede, Wim A, Sistem Pengendalian Manajemen, Jakarta: Salemba Empat, 2014.

Norman, Richard, Letting and Making Managers Manage: The Effect of Control Systems on Management Action in New Zealand's Central Government, New Zealand: Elsevier, 2001.

Oates, Grainne, Literature Review and Synthesis of Management Control Systems: in the Context of the Public Sector.,Canada : Canadian Center of Science and Education, 2015.

Peljhan, Darja., and Tekavčič, Metka, The Impact of Management Control System - Strategy Interaction on Performance Management : a Case Study., Ljubljana: Organizacija, 2008.

Pock, Thomas., Contingency-based Design of Management Control Systems, Dissertation, University of St. Gallen, Germany, 2007. 
Simons, R., Control in an Age of Empowerment, Boston: Harvard Business Review, 1995.

Levers of Control: How Managers Use Innovative Control Systems to drive Strategy Renewal. Boston: Harvard Business School Press, 1995.

Performance Measurement \& Control Systems for Implementing Strategy: text \& cases. New Jersey: Prentice Hall, 2000.

\section{Dokumen Publik dan Peraturan Perundang-Undangan}

Republik Indonesia. Undang-Undang Nomor 17 Tahun 2003 tentang Keuangan Negara.

Republik Indonesia. Peraturan Pemerintah Nomor 53 Tahun 2010 tentang Disiplin Pegawai Negeri.

Bappenas, Peraturan Menteri Negara Perencanaan Pembangunan Nasional Nomor 5 Tahun 2009 tentang Pedoman Penyusunan Rencana Strategis K/L 2010-2014.

Kementerian Keuangan, Peraturan Menteri Keuangan Nomor 009 Tahun 2007 tentang Kode Etik Pegawai di Lingkungan Badan Pendidikan dan Pelatihan Keuangan Departemen Keuangan Repubik Indonesia.

Keuangan Nomor 37 Tahun 2012 tentang Peningkatan Disiplin Pegawai Negeri Sipil Kementerian Keuangan Dalam Rangka Perwujudan Nilai-Nilai Kementerian Keuangan.

Peraturan Menteri Keuangan Nomor 85 Tahun 2015 tentang Perubahan Atas Peraturan Menteri Keuangan Nomor 214 Tahun 2011 tentang Penegakan Disiplin Dalam Kaitannya dengan Tunjangan Khusus Pembinaan Keuangan Negara di Lingkungan Kementerian Keuangan. 